\title{
Maternity Misplaced: The Infanticidal Mother Archetype in Fin-de-Siècle Australia and France ${ }^{1}$
}

\author{
Saskia Roberts
}

The Australian National University, Canberra, ACT

\begin{abstract}
In fin-de-siècle Australia and France, the public had recourse to an archetype that reconciled the 'unnatural' yet prevalent practice of infanticide with pronatalist anxieties and fears about changing gender divisions. By examining newspaper reports and fictional serials across the political spectrum, I reveal that the 'infanticidal mother' archetype worked to affirm, rather than challenge, contemporary ideals of motherhood. Journalists saw most infanticidal women as having 'misplaced', rather than lost, their maternal instinct; in so doing, they made these women redeemable after their 'slip into sin', linked their wellbeing directly to their mothering potential and dismissed the harrowing rationality of infanticide. The archetype could also be adapted to highlight political (counter)points, with feminists expressing utopian hopes and conservatives deriding a corrupting modernity. Previous histories situate infanticide within discussions of birth control or crimes of passion, yet commentators in both countries saw infanticide as different and distinctive. Taking a comparative approach underlines the infanticidal mother's unique cultural weight as both Australia and France drew on similar discursive scaffolding to produce and enforce an ideal of motherhood. These distant countries even occasionally looked to each other in their discussions of infanticide. By examining 'good', 'mad' and 'bad' infanticidal mothers, we see how the archetype neutralised threats to gender norms and, by extension, to the nation-state itself.
\end{abstract}

1 Many thanks to Frank Bongiorno, Maria Nugent, Owen McNamara, Amanda O’Connell and the two anonymous reviewers for their feedback. 
In 1898, the French feminist newspaper Le Journal des Femmes (18911911) published 'La Petite Mary', a roman-feuilleton (a fictional work in instalments, then common in newspapers). The titular character is a pregnant domestic servant; the 'petite' relating to 'her youth and inexperience, because she was innocence incarnate'. ${ }^{2}$ Mary is fired by her mistress, who escorts her to the maternity hospital. She is admitted on her charm alone, so captivating that the matron 'takes pity on this good woman' (who was, only paragraphs before, considered a child), despite 'being completely used to hearing pitiful confessions' from girl-mothers. ${ }^{3}$ Mary is not in contact with her child's father: 'he said he would send for me, but he never will ... I will never reunite with him because I hate him'. ${ }^{4}$ Mary's resignation is perhaps due to the fact that, by 1898 , legalisation of paternity suits had been dismissed in parliament several times. Women like Mary had been abandoned by two embodiments of patriarchy: their seducers and the state. ${ }^{5}$

In her final moments of pregnancy (and of the feuilleton's first instalment), Mary contemplates raising an illegitimate child alone:

she must see a little life blossom ... who had only the weak arms of a woman to protect him against a wicked world, in the eyes of which he could only be a pariah .... imagine yourself in the place of the poor girl for whom deliverance is a word that means nothing, for whom maternity offers little consolation ... Physical pain is nothing compared to this moral torture!

In the next instalment, Mary remains with her child. She protects it 'like a young tigress' and prays to her namesake-the Virgin Marywhen it is sick. ${ }^{7}$ But Mary has escaped her pre-ordained fate. For finde-siècle readers, this was a story about infanticide and, as a young, poor, earnest domestic servant, Mary was an iteration of the 'infanticidal mother' newspaper archetype. Mary's fears of 'moral torture' pre-empt the shame that could lead her to murder. In most infanticidal mother stories (fictional or otherwise), dread of the social opprobrium surrounding

2 Eugenie Potonié-Pierre, 'La Petite Mary [Part I]', Journal des Femmes, November 1898, 3. All translations mine.

3 Ibid.

4 Ibid.

5 Rachel Ginnis Fuchs, Contested Paternity: Constructing Families in Modern France (Baltimore: Johns Hopkins University Press, 2010), 117-22.

6 Potonié-Pierre, 'Mary [Part I]', 3.

7 Eugenie Potonié-Pierre, 'La Petite Mary [Part II]', Journal des Femmes, December 1898, 3. 
single motherhood drove the archetype to her crime. To understand why Mary's story ends differently, we need to examine Le Journal des Femmes and French feminism more broadly. What could feminists gain by using the archetype?

The trials and tribulations of motherhood were a regular theme in Le Journal des Femmes. Its radical editor, Maria Martin, would later disparage a proposal to combat depopulation that involved awarding a ribbon to mothers of large families. Martin sarcastically noted this ribbon would eradicate 'the sufferings and perils of childbirth, the fatigues of breastfeeding, the sleepless nights ${ }^{8}{ }^{8}$ But Martin and her fellow feminists did not want to abandon motherhood entirely. Instead, they dreamed of a utopia in which single women raised their children without shame, and with adequate social and financial support. Faced with criticism that their politics threatened the institution of motherhood, feminists argued that even women like Mary, at risk of infanticide, could make good mothers.

While French feminists used the archetype to highlight the arduousness of single motherhood, the infanticidal mother was a flexible shorthand, capable of being adapted to social and political concerns in fin-desiècle Australia and France alike. Present in fiction and non-fiction, from court reports to salacious tabloid copy, she remained a constant of both countries' presses. The main iteration of the archetype flattened a multiplicity of experiences into a woman not unlike Mary-young, poor, but a capable mother, if only given the chance. This 'good infanticidal mother' was a woman who killed reluctantly, and without cruelty, often smothering her child with a pillow or optimistically leaving it on a street, to be discovered by passers-by. The other iterations of the archetype built on this tragic figure, either heightening public sympathies by deeming her 'mad' or identifying a 'bad', heartless monster as her foil. Yet despite the threat infanticide posed to pronatalist rhetoric and gender divisions, all three iterations of the archetype worked to reify, rather than challenge, the idealisation of motherhood.

Both Australia and France were undergoing contestation over national identities, though France, due to its sharper political divisions, would have greater trouble reaching a resolution. Australia, moving toward unity as a federated commonwealth within the British Empire, attempted to fashion itself into a more egalitarian version of the mother country. 
The bush — a romantic term for Australia's countryside—allowed Australia to distinguish itself from Britain and provided a template for gender roles. Bohemian poets idealised the bushman, tied neither to a nagging woman nor the demands of the city; feminists, according to historian Marilyn Lake, saw the bush as 'mother to the settlers' and Australian women as nurturers of the 'infant Commonwealth'.?

The French Third Republic (1870-1940) had its shaky foundations regularly tested by political battles, many of which were linked to fears of family disintegration and women's increasing freedoms. Joshua Cole notes that 'family policy'-including laws about divorce, wet-nurses and girls' education-was a tool that 'anticlerical republican legislators increasingly used ... to distinguish themselves from their conservative Catholic opponents'. ${ }^{10}$ The press was both battle arena and combatant in these conflicts, as exemplified by the Dreyfus Affair (1894-1906). After the Jewish-French Captain Alfred Dreyfus was wrongfully convicted of espionage, a series of cover-ups, forgeries, further convictions and Dreyfus' eventual pardon cemented divisions between republicans and Catholics. According to Charles Sowerwine, this was 'the first political event to be fought in mass circulation newspapers'. ${ }^{11}$ While Emile Zola famously published his defence of Dreyfus, 'J'Accuse...!', in the socialist L'Aurore, conservative papers including $L a$ Croix used the affair to justify their extreme antisemitism. Though French society was undoubtedly more polarised than its Australian counterpart, both countries used the infanticidal mother to explore and reconcile their concerns about gender and the nation-state. Examining this newspaper archetype allows me to highlight local concerns while simultaneously revealing the connections these countries shared-connections that Anglophone studies have overlooked.

To uncover how the infanticidal mother was constructed and adapted, I have studied a selection of French and Australian newspapers from 1870 to 1914 . It was in the press that the archetype made its cultural impact, as the discourses of the courtroom, the medical office and the charitable

9 Marilyn Lake, 'Historical Reconsiderations IV: The Politics of Respectability: Identifying the Masculinist Context', Historical Studies 22, no. 86 (1986): 117-18; Marilyn Lake, 'Women and Nation in Australia: The Politics of Representation', Australian Journal of Politics \& History 43, no. 1 (2008): 46-47.

10 Joshua Cole, “'A Sudden and Terrible Revelation”: Motherhood and Infant Mortality in France, 1858-1874', Journal of Family History 21, no. 4 (1996): 422.

11 Charles Sowerwine, France since 1870: Culture, Politics and Society (New York: Palgrave, 2001), 70. 
institution mingled with the voices of the public through letters to the editor, leaders, court reports and fictional serials. In Australia, where a greater media consensus emerged, I focused on location, examining papers from capital cities and some regional towns. The press assumed an air of objectivity, publishing detailed reports covering the courtroom, the street and the morgue. Articles aimed to rehabilitate what Jill Matthews terms 'good' and 'mad' women, giving them permission to resume their pursuit of ideal motherhood. ${ }^{12}$

French newspapers, operating in a time of intense social division, had significantly clearer political allegiances than their Australian counterparts. This division guided my research. I consulted radical, conservative, sensational and feminist newspapers, among others. A contemporary obsession with crime meant the infanticidal mother was often the star of scandalous stories. Motivated by their turbulent context, French journalists used the archetype to understand a wider variety of cultural concerns, from secularism to consumerist culture. Commentators uncovered a third woman, the 'bad' archetype, who exemplified the novel ills of the Third Republic.

Despite their different reporting styles, placing the French and Australian press in dialogue reveals they used the archetype to similar ends, reflecting contemporaries' understandings of the countries' connections. By examining the fluctuations, repetitions and restructurings of what Sydney's Evening News labelled 'a pitiable story of seduction, desertion, and poverty', I expose France and Australia's shared obsession with motherhood and the expectation women would pursue it, even after shunning it so thoroughly. ${ }^{13}$ Such analysis contributes to the emerging literature on the entangled histories of these nations, geographically distant yet connected through intricate cultural webs. ${ }^{14}$

12 Jill Matthews, Good and Mad Women: The Historical Construction of Femininity in TwentiethCentury Australia (Sydney: Allen \& Unwin, 1984).

13 'Infanticide', Evening News, 30 November 1889, 5.

14 Alexis Bergantz, French Connection: Australia's Quest to Become a Cosmopolitan Nation (Sydney: NewSouth Books, 2021). 
In the existing literature, infanticide is often relegated to discussions of abortion or crimes of passion. ${ }^{15}$ Yet contemporaries in Australia and France recognised infanticide was different. Unlike abortion, it was not a characteristic crime of cosmopolitan, 'egotistical' women but of desperate, sympathy-inducing girls. Unlike vengeful attempts at wounding cheating husbands, it did not involve skilful planning. Separating infanticide from these issues and instead examining its representations in two distant countries reveals its unique discursive power.

Previous work documents the courtroom lenience shown to women who committed infanticide. In France, historians have uncovered a familyfocused sexual morality condemning the usual victims of infanticide: illegitimate children. ${ }^{16}$ Dominique Vallaud suggests these children were understood as 'menace[s] to the social order' who, unlike their legitimate counterparts, were not missed. ${ }^{17}$ This eugenicist perception fed into the archetype; the infanticidal woman, if given a second chance at motherhood, may produce more worthy stock. Australian historians, meanwhile, have focused on the babyfarmer. ${ }^{18}$ Shurlee Swain and Renate Howe assert this was 'a construct deliberately created to divert attention

15 Ann-Louise Shapiro, Breaking the Codes: Female Criminality in Fin-de-Siècle Paris (Stanford: Stanford University Press, 1996); Karen E. Huber, 'Sex and its Consequences: Abortion, Infanticide, and Women's Reproductive Decision-Making in France, 1901-1940' (PhD thesis, Ohio State University, 2007); Judith A. Allen, Sex \& Secrets: Crimes Involving Australian Women since 1880 (Melbourne: Oxford University Press, 1990).

16 Brigitte H. Bechtold, 'Infanticide in 19th Century France: A Quantitative Interpretation', Review of Radical Political Economics, 33, no. 2 (2001): 165-87; Silvia Chiletti, 'Grossesses ignorés au prisme de l'infanticide. Savoirs médicaux et décisions de justice au XIX siècle', Revue d'histoire du XIX'e siècle, 50 (2015): 165-79; Jonathan Dalby, 'Women and Infanticide in Nineteenth-Century Rural France', in Engendering History: Caribbean Women in Historical Perspective, ed. Verene Shepherd, Bridget Brereton, Barbara Bailey (London: James Currey, 1995), 337-68; James Donovan, 'Infanticide and the Juries in France, 1825-1913', Journal of Family History, 16, no. 2 (1991): 157-76; Rachel Ginnis Fuchs, Poor and Pregnant in Paris: Strategies for Survival in the Nineteenth Century (New Brunswick: Rutgers University Press, 1992); Simone Geoffroy-Poisson, 'L'infanticide devant la cour d'assises de la Haute-Marne au XIX siècle', Les Cahiers du Centre de Recherches Historiques, 35 (2005): 1-19; Huber, 'Sex and its Consequences'; Richard Lalou, 'L'infanticide devant les tribunaux français (1825-1910)', Communications, 44, no. 1 (1986): 175-200; Marie-Agnès Mallet, 'Maîtres et servantes: des histoires d'infanticide, France XIX ${ }^{\mathrm{e}}$ siècle', Projets Féministes, 1 (1992): 1-5; Daniela Tinková, 'Protéger ou punir? Les voies de la décriminalisation de l'infanticide en France et dans le domaine des Habsbourg (XVIII ${ }^{\mathrm{e}}$ - XIX ${ }^{\mathrm{e}}$ siècles)', Crime, Histoire et Sociétés, 9, no. 2 (2005): 43-72.

17 Dominique Vallaud, 'Le crime d'infanticide et l'indulgence des cours d'assises en France au XIXème siècle', Information sur les Sciences Sociales, 21, no. 3 (1982): 491.

18 Jan Kociumbas, 'Azaria's Antecedents: Stereotyping Infanticide in Late Nineteenth-Century Australia', Gender \& History, 13, no. 1 (2001): 138-60; Lucy Sussex, 'Portrait of a Murderer in Mixed Media: Cultural Attitudes, Infanticide and the Representation of Frances Knorr', Australian Feminist Law Journal 4 (1995): 39-54. A babyfarmer was a mercenary wet-nurse responsible for the deaths of children in her care, often through intentional starvation and neglect. 
from the reality that mothers did kill'. ${ }^{19}$ As I examine later, much of the archetype's cultural weight derived from this juxtaposition. The 'good' infanticidal mother was passive, irrational and innocent; her foil, the babyfarmer, was calculating, money-hungry and culpable.

More recent Australian work considers representations of infanticidal women, particularly in newspapers. Georgina Rychner analyses Margaret Heffernan's infanticide case, in which a public campaign for commutation of her death sentence cast Heffernan as mad. This case 'created a maelstrom into which the public cast social grievances'; as I detail below, Heffernan was not alone in having her trial politicised. ${ }^{20}$ Nicolá Goc explores infanticide discourses in Tasmanian and English newspapers. Goc avoids typical fin-de-siècle cases, examining two murders of children (as opposed to newborns) and two cases from early colonisation. She concludes that in Australia 'infanticide remained off political and social agendas' and that studying it provides 'no new insight into the representation of infanticide and the infanticidal woman in press discourse'. ${ }^{21}$ Her study evades the moment infanticide appeared on these agendas, as pronatalist preoccupations collided with fears of the 'fallen woman'. Examining a wider variety of newspapers, and conducting a comparison outside the Anglophone sphere, reveals that the infanticidal woman can tell us much about gender, motherhood and the state.

This article extends previous analysis on the cultural weight of the criminal woman to the infanticidal mother. Ann-Louise Shapiro characterises the French criminal woman as 'a lightning rod that gathered the social and cultural tensions of the period'. ${ }^{22}$ Shapiro sees the infanticidal mother as the exception to the rule, arguing, like Goc, that 'the poor and desperate murdering mother did not inhabit the same imaginative space' as other criminal women. ${ }^{23}$ The infanticidal mother undoubtedly belonged to a distinct space, separate from her peers. By examining Australia and France alike, I uncover this space-one in which ideal motherhood was both discursive tool and ultimate goal.

19 Shurlee Swain and Renate Howe, Single Mothers and Their Children: Disposal, Punishment and Survival in Australia (Cambridge: Cambridge University Press, 1995), 100.

20 Georgina Rychner, 'Murderess or Madwoman? Margaret Heffernan, Infanticide and Insanity in Colonial Victoria', Lilith: A Feminist History Journal, no. 23 (2017): 91.

21 Nicolá Goc, Women, Infanticide, and the Press, 1822-1922: News Narratives in England and Australia (Farnham: Ashgate, 2013), 5.

22 Shapiro, Breaking the Codes, 7.

23 Ibid., 133. 


\section{The Ideal Mother}

The fin-de-siècle period was characterised by flux, particularly regarding gender. According to John Docker, in Australia 'everything seemed open to question'. ${ }^{24}$ Elaine Showalter notes Europeans' unease that 'sex roles might no longer be contained within the neat and permanent borderlines of gender categories. ${ }^{25}$ Showalter conceptualises the ends of centuries as understood through 'the metaphors of death and rebirth'. ${ }^{26}$ The idea of birth and its potential for change was noticeably present in Australian and French thought.

While France felt 'reborn' with the advent of the Third Republic, white Australia was in its first blush of youth. Feminist Louisa Lawson characterised Australia as a 'girl-mother', a term often used for infanticidal women. ${ }^{27}$ Like these women, Australia could be exploited by the powerful; protection could be created through increases to the white population. Fears of Asia grew as the birth-rate declined: married women, on average, gave birth to seven children in 1870 , but only four by $1900 .{ }^{28}$ France also wrestled with fears of national decay in the wake of defeat in the FrancoPrussian war. While Germany grew demographically and militarily, France's birth-rate dropped from 26 to 19 per thousand between 1870 and $1911 . .^{29}$

Depopulation anxieties reached their climax in the early twentieth century and were encapsulated and exacerbated by commissions in both countries. Studying these enquiries reveals the connections between Australian and French thought. Both the French Commission into Depopulation (beginning 1902) and the New South Wales Royal Commission on the Decline of the Birth-rate (1903-04) saw women who procured birth control as prioritising pleasure over procreation. As per their remarkably similar reports:

24 John Docker, The Nervous Nineties: Australian Cultural Life in the 1890s (Melbourne: Oxford University Press, 1991), xv.

25 Elaine Showalter, Sexual Anarchy: Gender and Culture at the Fin de Siècle (New York: Viking, 1990), 2, 9.

26 Ibid., 9.

27 Louisa Lawson, 'A Plea for Australia', in The Lonely Crossing and Other Poems (Sydney: The Dawn Office, 1905), 34 .

28 Allen, Sex \& Secrets, 67.

29 Anne Cova, 'French Feminism and Maternity: Theories and Policies 1890-1918', in Maternity and Gender Policies: Women and the Rise of the European Welfare States, 1880s-1950s, ed. Gisela Thane and Pat Bock (London: Routledge, 1994), 119. 
Currently a certain number of women quite simply state that they have had abortions ... the most shocking cynicism is manifest in these confessions. They admit to procuring abortion without hesitation, without prudence. ${ }^{30}$

So many women do not realise the wrong involved in ... abortion. They converse with one another upon these subjects apparently without shame, and freely approach doctors and chemists ... to gratify their desires. ${ }^{31}$

The links extend beyond a resemblance in language. The Australian Royal Commission on Secret Drugs, Cures, and Foods (1906-07) viewed France as a nightmare vision of Australia's reproductive future. Although many Western countries were experiencing a decline in birth-rates, Australia's 'correspond[ed] more nearly with those of France ... it is hoped that the contemplation of advanced decadence may afford another reason for protecting the health and lives of Australian mothers, girls, babies and embryos' ${ }^{32}$ Comparison with a nation the Australian press painted as depraved and dismally infertile must have struck terror in the hearts of pronatalists. It also reveals an international focus; to contemporaries, juxtaposing Australia with France felt more appropriate than comparison with other members of the British Empire. Indeed, while French feminists envied their Australian counterparts' suffrage (particularly as a tool to increase paternal responsibility), Australian journalists gazed longingly (and erroneously) at France's obsolete tours, where babies could be anonymously deposited, as a means to discourage infanticide. ${ }^{33}$

Pronatalism led to a discursive emphasis on innate maternal instinct, recalling Matthews' assertion that the 'central icon' of the era's 'population ideology' was the 'Ideal Mother'. ${ }^{34}$ While it was impossible for women to conform to this ideal, the natural world provided them with examples to approximate. Marion Thomas' exploration of French scientific studies notes naturalist Edmond Perrier's 1908 argument that, as in the animal kingdom, a 'healthy and normal Woman ... is herself essentially

30 Jean Marie Joseph Fabre quoted in Gustave Drouineau, Commission de la Dépopulation: Rapport sur l'influence des avortements criminels sur la dépopulation et les mesures à prendre (Melun: Imprimerie Administrative, 1908), 10.

31 Royal Commission on the Decline of the Birth-rate and on the Mortality of Infants in New South Wales, Report: Volume I (Sydney: William Applegate Gullick, Government Printer, 1904), 23.

32 Royal Commission on Secret Drugs, Cures and Foods, Report (Sydney: William Applegate Gullick, Government Printer, 1907), 36.

33 'Le Suffrage des Femmes en Australie', Journal des Femmes, January 1904, 3; Age, 15 June 1899, 4.

34 Matthews, Good and Mad Women, 75. 
a mother'. ${ }^{35}$ The Australian press similarly abounded with references to animal nature. An article by American suffragist Tennessee C. Claflin, reprinted in several regional newspapers, emphasised:

The feeling which governs alike the incubation of the lowly earwig and the stately pheasant ... that universal impulse which conserves the family, the species, the race — cannot be diverted ... unless our moral sentiments and our laws also operate against it. ${ }^{36}$

Motherhood was part of nature's order; a corrupting modernity allowed the infanticidal woman to act against instinct, to momentarily defy the commanding pull of the Ideal Mother.

The symbolic power of motherhood was partially due to its newfound presence in medical thought. Doctors and politicians campaigned for maternal breastfeeding, condemning the mercenary wet-nurse or babyfarmer. ${ }^{37}$ Backlash intensified in Australia after corpses were discovered in child-minders' backyards. These children had been killed or starved after lump-sum payments were received for their care. ${ }^{38}$ In France, the 1874 Roussel Law placed wet-nurses under government surveillance. ${ }^{39}$ This law found its equivalent in several Australian Infant Life Protection Acts, which enforced registration of carers and banned lump-sum fees. ${ }^{40}$ However, many women could not afford regular payments and were frightened by government intrusion into traditional networks. As both scandals and legislation mounted, pregnancy and mothering fell under the nascent sub-discipline of paediatrics, which Lisa Featherstone describes as 'justified by the relationship of the child to the future adult'. ${ }^{41}$ Women were to devote themselves to their children; breastfeeding would serve the same nation-building purpose as army enlistment. ${ }^{42}$

35 Edmond Perrier, La femme dans la nature, dans les mours, dans la légende, dans la société. Tableau de son évolution physique et psychique (Paris: Bong et Cie, 1908), 12, in Marion Thomas, 'Are Women Naturally Devoted Mothers?: Fabre, Perrier, and Giard on Maternal Instinct in France Under the Third Republic', Journal of the History of the Behavioral Sciences 50, no. 3 (2014): 293.

36 Lady Cook née Tennessee C. Claflin, 'Infanticide', Kapunda Herald, 26 June 1896, 4. Also printed in Wagga Wagga Express, Port Augusta Dispatch, Newcastle and Flinders Chronicle and Kadina and Wallaroo Times.

37 Kociumbas, 'Azaria’s Antecedents',147-48; Fuchs, Poor and Pregnant in Paris, 62.

38 Kociumbas, 'Azaria's Antecedents', 143.

39 Cole, "'A Sudden and Terrible Revelation", 419.

40 Swain and Howe, Single Mothers, 111.

41 Lisa Featherstone, 'The Value of an Infant: The Rise of Paediatrics in Australia, 1880-1910', Health and History, 10, no. 1 (2008): 113.

42 Fuchs, Poor and Pregnant in Paris, 62. 
Pregnant single women found themselves in a financially and socially tenuous position. While women entered the workforce in greater numbers, their wages remained too low to support children. ${ }^{43}$ The French tours were replaced by offices where women's details were registered, exacerbating fears of government scrutiny. ${ }^{44}$ In Australia, a handful of foundling hospitals existed in name only. Unlike in other countries, these forced the mother to remain with her child to encourage maternal feeling. ${ }^{45}$ The usual means of birth control-pessaries, sponges and condomswere expensive. Abortion, additionally, was risky and illegal. ${ }^{46}$ Faced with a dearth of alternatives, some women used infanticide to solve the dilemma of pregnancy.

In both countries, infanticide was legally considered murder, and was punishable by death. But instead of discouraging the practice, harsh laws moved juries to acquit or apply lesser sentences. It is easy to imagine juries of men who were acquainted with the sympathetic infanticidal mother archetype, who were cognisant of the financial burden another child would place on their own families, or who were themselves 'seducers' who duped these types of women. Proving infanticide was also difficult. Women often swore their children were born dead. ${ }^{47}$ Medical experts could rarely prove them wrong, especially when many women resorted to suffocation or exposure, leaving little trace of their crime. ${ }^{48}$

The 1810 French penal code labelled infanticide assassinat ('pre-meditated murder'), as opposed to the lesser meurtre ('murder'). Later laws allowed for reduced punishment, but did not make proving murderous intent easier. ${ }^{49}$ Juries resorted to other charges: Richard Lalou records 26,503 cases of infanticide, manslaughter and suppression d'enfant, including those dismissed or dropped, between 1871 and 1910.50 By 1838-

43 Cole, "A Sudden and Terrible Revelation", 421; Shurlee Swain, 'Infanticide, Savagery and Civilisation: The Australian Experience', in Killing Infants: Studies in the Worldwide Practice of Infanticide, ed. Brigitte H. Bechtold and Donna Cooper Graves (Lewiston: Edward Mellen Press, 2006), 103.

44 Fuchs, Poor and Pregnant in Paris, 219.

45 See, for instance, 'The Infants' Home', Evening News, 3 September 1884, 6.

46 Frank Bongiorno, The Sex Lives of Australians, 2nd ed. (Melbourne: Black Inc., 2015), 69-72; Angus McLaren, Sexuality and Social Order: The Debate Over the Fertility of Women and Workers in France, 1770-1920 (New York: Holmes \& Meier, 1983), 24-25.

47 See, for example, 'Alleged Infanticide', Advertiser, 4 September 1899, 5; 'Autour de Paris', Petit Journal, 25 April 1890, 3.

48 Lalou, 'L'infanticide devant les tribunaux français', 194.

49 Ibid., 189.

50 Ibid., 181, Table 1. 
six years after juries were allowed to consider extenuating circumstancesthe application of the death penalty for infanticide had plunged to 4.7 per cent; it was no longer in use by $1891 .{ }^{51}$ Lesser penalties included five years of imprisonment or forced labour. ${ }^{52}$

Charges varied across Australia but resembled those in France. Infanticide was legally murder, but women were often charged with manslaughter, child abandonment or concealment of birth, and given six months to four years imprisonment, sometimes less. ${ }^{53}$ Judith Allen records 95 indictments of women in the New South Wales Supreme Court for infanticide and related crimes between 1880 and 1899; many of the women were not charged. ${ }^{54}$ This figure contrasts with the number of infant bodies found in this period-nearly 300 in Sydney alone, and 20 to 30 annually in Victoria. ${ }^{55}$ Swain and Howe uncover 157 cases of infanticide in Victoria between 1850 and 1915, with 30 women charged and found guilty. ${ }^{56}$ These figures, undoubtedly, represent the tip of the iceberg.

The ubiquity of infanticide seems to prove that many women failed in their pursuit of ideal motherhood. Yet commentators saw infanticide as a 'slip' into sin, a speedbump on a long road. According to Matthews, 'there are a multitude of ideals of good women ... a pinnacle from which the variety of less good positions slide, eventually falling into the anti-ideal of the bad woman'. ${ }^{57}$ The infanticidal mother inhabited a slippery slope; her crime could place her one step further along a path of vice. Having ignored her maternal instincts, she was in danger of losing them entirely, approaching the 'anti-ideal'.

\section{The Good}

The good infanticidal mother archetype was predicated upon what I term the 'misplaced maternal instinct'. I borrow this from Karen E. Huber's research into the courtroom performances of French women. Huber notes that 'it helped a woman's chances enormously if she could convince the

51 Ibid., 190.

52 Ibid., 189-190.

53 Allen, Sex \& Secrets, 33; Swain and Howe, Single Mothers, 96.

54 Allen, Sex \& Secrets, 29-30.

55 Ibid., 31; Swain and Howe, Single Mothers, 91.

56 Swain and Howe, Single Mothers, 94, 96.

57 Matthews, Good and Mad Women, 16. 
jury that her maternal instinct was only temporarily misplaced and that she did not actually reject motherhood wholesale' ${ }^{58}$ The infanticidal mother's maternal instinct had been suppressed, but not lost entirely. In her crisis she was, according to Sydney's Evening News in 1884, 'rendered callous to the strongest and purest instincts of woman's nature. ${ }^{59}$ She should be pitied for her defective performance of motherhood, not chastised. As the Sydney Morning Herald remarked in 1880, 'we know no more pitiable object ... than a fallen woman ... sweet motherhood known to her only [as] a sin, a curse, and a shame'. ${ }^{60}$ In a society that idealised motherhood, the problem must lie with the woman, not her economic circumstance. Motherhood was 'sweet', even in poverty; the infanticidal mother had mistaken a gift as a 'curse'.

In Australia, explanations of infanticide initially pointed to the degenerating influence of the city, later developing into a eugenicist response to pronatalism. Underpinning these was an understanding of young, poor women as dangerously susceptible to vice. In 1873, Melbourne's Catholic Advocate asserted that infanticide is one of those crimes with which civilisation $\ldots$ is chargeable ${ }^{61}$ Cities' inherent immorality encouraged infanticide; as young women became more publicly visible, heading to workplaces and social events, they were more likely to be led astray. As the birth-rate declined further, the situation became more precarious: 'Tommy Trot', describing Melbourne's infanticide problem for the Launceston Examiner in 1888, mused that 'the purity of a young girl's soul is like the delicate bloom on a peach ... a touch can rub it off, but no skill can put it back'. ${ }^{62}$

Yet not all agreed that civilisation corrupted. Others worried that a lack of it caused infanticide, degrading white Australia to the status of 'primitive' societies. In 1886, Melbourne's conservative Argus pictured 'some intelligent almond-eyed student ... writing to Pekin[g] descriptions of the hapless fate of illegitimate children ... averring that the common practice is to kill these little ones at birth, and to leave the bodies about the streets'. ${ }^{63}$ The liberal Age noted in 1890 that 'the slaughter of the innocents is almost as common ... [as] in countries ... [we] look down

58 Huber, 'Sex and its Consequences', 204.

59 Evening News, 10 October 1884, 2.

60 Sydney Morning Herald, 1 June 1880, 6.

61 'Infanticide', Advocate, 26 July 1873, 11.

62 'Tommy Trot', 'Echoes of the Street', Launceston Examiner, 28 November 1888, 3.

63 Argus, 18 September 1886, 8. 
upon with a half-contemptuous commiseration'. ${ }^{64}$ Australia was perhaps more like a 'girl-mother' than Lawson envisaged. Infanticide belied her embodiment of civilisation just as it hindered a woman's progress toward ideal motherhood.

Later, eugenic thinking intensified fears of corruption-just as the modern city had degraded these women, so too would it taint their illegitimate offspring-yet pointed to infanticide as reasonable response, rather than pernicious symptom. As the Age moralised in 1909: 'what must be the fate of infants born of such parents, if not an early death or a debased and diseased manhood?' ${ }^{\prime 5}$ Both pronatalist and eugenicist rhetoric fuelled fears of depravity. The latter prevailed in early twentieth-century discussions of infanticide, cementing the belief that 'good' infanticidal women should attempt motherhood again. These women could hardly be unnatural and irredeemable when they had mitigated a future national burden.

Regardless of whether a morally contaminated civilisation was cause or effect, the infanticidal mother was a victim of circumstance. An 1893 letter to the Sydney Morning Herald explained:

It is not the hardened in crime who fall into this most pitiful of shames; it is ... the timid, respectable girl who is led away by her too loving, trusting nature ... It is the exposure, the shame, which the miserable mother cannot endure which makes her murder the poor, unoffending little baby. ${ }^{66}$

The infanticidal mother was still within the realm of respectability, contradicting Swain's contention that these women 'for their uncontrolled sexuality ... had to be publicly branded and placed outside the pale of respectable society'. ${ }^{67}$ The archetype was too passive to be promiscuousshe was 'led away' by her seducer; she did not choose to 'fall' herself. Such representations distilled multiple infanticides-which could be cruel, calculated and not motivated by shame-into an archetype that denied women agency in their crimes, rendering them helpless and innocent.

64 Age, 5 March 1890, 4.

65 Age, 7 August 1909, 12.

66 'Infanticide in Sydney', Sydney Morning Herald, 4 July 1892, 7.

67 Shurlee Swain, 'The Concealment of Birth in Late Nineteenth-Century Victoria', Lilith: A Feminist History Journal, no. 5 (1988): 146. 
The infanticidal mother had long been understood as irrational, even prior to the popularisation of puerperal mania (see below) as an explanation for her actions. Her crime was not due to economic circumstance: this implied a level of calculation too cold for a figure deserving rehabilitation. In the above letter, 'Foundling' postulated that infanticide was not due to 'a want of funds' but shame: 'a mother will work for her child ... but she cannot endure public exposure and scorn'. ${ }^{68}$ As early as 1873 , the Mount Alexander Mail hinted at lunacy leading to infanticide. These women were 'so young, so ignorant, and so desperate, that when they see their shame they are all but maddened to destroy ... their offspring' ${ }^{69}$ Infanticidal mothers were often domestic servants, meaning their accommodation and income were at stake if they became pregnant. Despite acknowledging these circumstances, commentators insisted these women were driven by shame. A moment of feeble irrationality, the act of infanticide was 'unnatural', the infanticidal mother was not. When crime and criminal were separated discursively, the infanticidal mother's reasoning need not be interrogated, nor her mothering potential questioned. This separation would later allow commentators to create the (temporarily) 'mad' archetype, who was particularly deserving of a fresh chance at motherhood.

Infants' homes were founded on the premise that maternal instinct was rarely revoked entirely. According to the South Australian Advertiser in 1899, 'maternal affection sometimes needs time to develop'. ${ }^{70}$ At the Destitute Asylum of Adelaide, 'mothers are compelled to remain till the children born there are six months old ... allowing time for the development of proper maternal feeling..$^{71}$ Arguments against foundling hospitals were predicated on the same notion. The Secretary of the Industrial and Reformatory Schools, George Guillaume, affirmed that if a mother did not have her maternal instincts awakened and exercised in the nursing of her child, her moral tone is at once lowered, and she is unquestionably a more ready prey to a new temptation'. ${ }^{72}$ While the maternal instinct lay dormant, the infanticidal mother was vulnerable. If it were lost, she could be cast onto a path of sin, forgoing any chance of redemption.

68 'Infanticide in Sydney', 7.

69 'Infanticide and Seduction', Mount Alexander Mail, 15 May 1873, 3.

70 Advertiser, 23 August 1899, 4.

71 Ibid.

72 'The Charities Commission', Argus, 6 December 1890, 12. 
While both conservative and liberal newspapers in Australia adopted the good infanticidal mother archetype, their French colleagues did not achieve the same consensus. French newspapers wore their political leanings on their sleeves, with iterations of the archetype differing accordingly. Later, I examine how the bad infanticidal mother served conservative Catholics. As evident in 'La Petite Mary', her good counterpart proved useful for feminists. Other left-leaning fictional texts also embraced ideal motherhood while using the archetype to critique the Third Republic. An example is 'La Bretonne' by playwright André Theuriet, published in the radical La Lanterne in 1888 and the sensationalist Le Petit Parisien in $1890 .{ }^{73}$

The story begins with the infanticidal mother, La Bretonne, leaving jail in Auberive. She walks into the night, hinting at her potential turn toward prostitution. La Bretonne is saved from hunger and the cold by La Fleuriotte, the woman she might have been. Despite her poverty, La Fleuriotte allows La Bretonne to stay with her. Her husband is dead and her child is seven-a convenient coincidence given La Bretonne's crime occurred six years earlier. La Bretonne hears La Fleuriotte tell her daughter they are too poor to purchase St Catherine's Day gifts. Thinking of her own dead child, La Bretonne feels an 'explosion of tenderness [which] awakened a muffled maternal instinct, buried in the breast'. ${ }^{74}$ After a sleepless night, she rushes to Auberive to buy every available toy. Her plan seems foiled when a policeman arrests her-she is not allowed this close to the jail. But the policeman, 'good at the bottom of his heart', lets her deliver the presents, wiping away tears as she returns to his carriage. ${ }^{75}$

La Bretonne has not relinquished motherhood, despite her infanticide. Nor has she been corrupted by France's burgeoning consumerism: women were seduced not only by men but by what Shapiro terms the 'dazzling sensuality' of the department store. ${ }^{76}$ Unlike materialistic shoplifters, $\mathrm{La}$ Bretonne's purchases are selfless, revealing her maternal instinct. She is remote from modern yet morally decayed Paris, symbolised by the striking yet precarious Eiffel Tower, built in the year between the

73 André Theuriet, 'La Bretonne', Lanterne: Supplément Littéraire, 11 November 1888, 1; also in Petit Parisien: Supplément Littéraire Illustré, 2 February 1890, 4-5. The following references are from Lanterne.

74 Theuriet, 'La Bretonne', 1.

75 Ibid.

76 Shapiro, Breaking the Codes, 126. 
story's publications. ${ }^{77}$ The rurality of La Bretonne and her role-play as St Catherine contrast with the contaminating ostentation of the city. For Theuriet, the Ideal Mother must eschew urbanity.

While the good infanticidal mother was not confined to fiction, this allowed French commentators to mobilise the archetype for their political projects more than was possible in Australia. 'La Bretonne' evokes a bucolic past, in which infanticidal women could retrieve their maternal instincts. As the twentieth century approached, texts like 'La Petite Mary' substituted nostalgia with forward-looking, utopian visions. In Australia, too, new ideas mutated the archetype.

\section{The Mad}

The denial of the rationality of infanticide reached its zenith in the focus on puerperal mania, which caused mothers to become violent and occasionally murder their children. This illness was documented as early as $1820 .{ }^{78}$ However, there was little consensus regarding its symptoms and how and by whom they should be treated. What had been established was that puerperal mania was a form of 'puerperal insanity', which also manifested as melancholia or dementia, or as all three in stages. ${ }^{79}$ It occurred in women experiencing extremes-so habituated to luxury that pregnancy traumatised them, or living in such poverty that it pushed them toward insanity ${ }^{80}$ Women giving birth to illegitimate children were more likely to experience the illness, which supposedly left them with no memory of infanticide, nor any symptom by the time of their trial. ${ }^{81}$ Accordingly, both French and Australian women charged with infanticide often claimed they had 'lost their heads'. ${ }^{82}$

77 Sowerwine, France since 1870, 54.

78 Robert Gooch's 1820 Observations on Puerperal Insanity is the first account of this illness in English. See Hilary Marland, 'Getting Away with Murder? Puerperal Insanity, Infanticide and the Defence Plea’, in Infanticide: Historical Perspectives on Child Murder and Concealment, 1550-2000, ed. Mark Jackson (Aldershot: Ashgate, 2002), 174.

79 Ibid., 176.

80 Hilary Marland, 'Disappointment and Desolation: Women, Doctors and Interpretations of Puerperal Insanity in the Nineteenth Century', History of Psychiatry 14, no. 3 (2003): 309.

81 Marland, 'Getting Away with Murder?', 181.

82 Rychner, 'Murderess or Madwoman?', 94; Shapiro, Breaking the Codes, 130. 
Although puerperal mania was a regular defence in French courts, leading pathologists remained unconvinced it existed. Ambroise Tardieu, Dean of the University of Paris Faculty of Medicine, wrote in 1868 that violent behaviour during childbirth was not 'a transitory perversion of the faculties, it ... leaves reason and instincts intact'. There was 'an impassable abyss' between this 'overexcitement of sensitivity' and madness. ${ }^{83}$ While Tardieu believed prior madness could drive women to infanticide, he denied the existence of puerperal mania. ${ }^{84} \mathrm{~A}$ forensic expert in hundreds of cases, Tardieu's opinion carried weight. His successor as dean, fellow forensic expert Paul Brouardel, agreed, claiming in 1897: 'nothing in our knowledge of mental pathology allows us to accept such a pathological phenomenon as true. ${ }^{85}$ Tardieu cautioned against the distraction of 'the sentiment of commiseration which one naturally feels towards these poor, seduced girls'; Brouardel noted that 'if the juries take pity, I will not object'. ${ }^{86}$ However, both maintained puerperal insanity was the tool of a good defence lawyer, not a legitimate madness.

The Australian medical community felt differently. In 1895, the president of the British Medical Association's Victorian branch, Felix Mayer, described puerperal mania as part 'of the wonderful inter-dependence that exists between the special organs of woman and her nervous system ... a woman is an organism round about a uterus ${ }^{8}{ }^{87}$ In 1903, W. Beattie Smith, president of the Ballarat branch, noted that 'distrust and suspicion practically represent the condition, and voices or delusional promptings account for the tendency to the murder of the ... child' ${ }^{88} \mathrm{He}$ maintained that 50 per cent of those afflicted were 'impulsively dangerous to others' ${ }^{89}$ For the Australian medical community, puerperal mania was real and required its attention.

Australian doctors found confirmation of their beliefs in the 1884 trial of Rosanna Plummer, who, at first glance, embodied the 'good' archetype. Rosanna's case was an early example of the press's fascination with this illness, and illustrates commentators' creation of the 'mad' archetype.

\footnotetext{
83 Ambroise Tardieu, Étude médico-légale sur l'infanticide (Paris: J-B Baillière, 1868), 230.

84 Ibid., 234.

85 Paul Brouardel, L'infanticide (Paris: J-B Baillière, 1897), 164.

86 Tardieu, Étude médico-légale, 240; Brouardel, L'Infanticide, 165.

87 Felix Mayer, 'British Medical Association, Victorian Branch: President's Address', Australian Medical Journal, 20 January 1895, 28.

88 W. Beattie Smith, 'Presidential Address: Insanity in its Relations to the Practitioner, the Patient, and the State', Intercolonial Medical Journal of Australia 8, no. 2 (1903): 67.

89 Ibid., 68.
} 
Rosanna was seduced by a farmer, who refused to support her. Unlike other infanticidal women, she did not conceal her condition and prepared for motherhood by sewing children's clothes. Rosanna travelled from Benalla to the more anonymous Melbourne, giving birth at Dr Singleton's Retreat for Friendless and Fallen Women. According to a petition for the commutation of her death sentence, in the fortnight her baby was alive 'she had always shown [it] a mother's love'. ${ }^{90}$

The day her mother was to collect her, Rosanna smothered her child in a railway station, carrying it in a bag to the Retreat. Rosanna admitted to the murder, despite initially claiming the child was with her mother. She probably saw no alternative when the baby's hand and foot poked out of the bag. ${ }^{91}$

These actions were construed as signs of puerperal mania. Like other infanticidal mothers, Rosanna was 'an unfortunate creature' who committed a 'heartless child murder'. ${ }^{92}$ Act and actor were again discursively separate, reducing her culpability. Unlike others, Rosanna was not acquitted or given a lesser sentence: she was condemned to death, eventually receiving a pardon. It was her reaction to arrest that most surprised commentators. Dr Singleton wrote that:

she is not of sound mind, and seems not to realise her present sad position. She is a soft, good-natured girl ... I was struck with her apparent childish conduct at the Home, as well as at the inquest, where she was looking out the window, and appeared quite unconcerned. ${ }^{93}$

Possibly Rosanna was too 'childish' to realise her 'present sad position'. But it is more likely that her inability or refusal to perform the role of grieving mother, combined with her 'soft' disposition, meant she could only be comprehended as mad. Huber observes that 'from the newspapers the public and jurors learned what to expect from "sympathetic" criminals. ${ }^{94}$ Rosanna would have partially matched these descriptions. According to her petitioners, she had 'an open innocent face [that] forbade the thought' that she was capable of infanticide. ${ }^{95}$ But as the Argus noted, 'the evidence

90 'The Condemned Girl, Rosanna Plummer', Age, 28 July 1884, 6.

91 'The Case of Infanticide', Age, 26 June 1884, 5.

92 'Heartless Infanticide', Argus, 24 June 1884, 7.

93 Argus, 22 July $1884,5$.

94 Huber, 'Sex and its Consequences', 190.

95 E. C. Ball, 'Rosanna Plummer's Release', Telegraph, St Kilda, Prahran and South Yarra Guardian, 30 August 1884, 5. 
against the girl was her own confession, which was so plain ... the jury could not evade it'. ${ }^{96}$ She admitted her actions, her unguardedness contrasting with the denials expected of good infanticidal mothers. Neither sympathetic nor monstrous, she must have been incapacitated. It was through examples like Rosanna that the second iteration of the archetype was created-the mad infanticidal mother.

This was an early iteration of a trope that dismissed the harrowing rationality of infanticide. Although Rosanna's pregnancy was public knowledge, her outlook was bleak. Her child would be illegitimate and have poor social prospects. Her admittance to the Retreat suggests her unenviable economic circumstances. Rosanna killed her child just before her mother's return-perhaps she doubted her support. If Rosanna had expressed remorse, or denied her crime more vehemently, she would have fitted the archetype of the good infanticidal mother. But her failure to do so meant her actions were understood through the prism of madness.

Rosanna's case was the logical extension of commentators' separation of act and action, and provided a template for several high-profile infanticides said to involve puerperal mania. The illness was taken more seriously at the turn of the twentieth century, including in France. By then, the rise of pronatalism made infanticide more difficult to swallow, and, in Australia, 1890s babyfarming scandals had cemented the divide between 'good' and 'bad' infanticidal mothers. ${ }^{97}$ Madness became a useful in-between state; according to Rychner it allowed commentators to 'support' women 'without any implied justification of murder'. ${ }^{98}$ In France, Rosanna could have been construed as a different iteration of the archetype, one that right-wing journalists mobilised in their crusades against anticlericalism, modernity and French Jews in an era of intense ideological conflict.

\section{The Bad}

The 'bad' infanticidal mother was a wolf in sheep's clothing, intentionally replicating the good archetype to disguise her evil nature. Some of these women were once good, but after their first 'slip' had evaded redemption. The policy of Australian benevolent societies reflected this idea; at the

96 Argus, 12 August 1884, 4.

97 Rychner, 'Murderess or Madwoman?', 92; Tinková, 'Protéger ou punir?', 13.

98 Rychner, 'Murderess or Madwoman?', 98. 
Infants' Home, 'no woman is received with a second illegitimate child; nor has the Home ever received a woman who has made a living by vice. ${ }^{9} 9$ Infanticidal mothers were given one chance only, otherwise 'nothing remains to them but to sink lower and lower, and eventually become burdens on the State.' ${ }^{100}$

The bad infanticidal mother was gruesome and calculating in her crime, the funhouse-mirror of the good archetype. Conservative French newspapers detailed 'true' stories of women who burned their children to death, cooked them in pots or fed them to pigs. ${ }^{101}$ These newspapers dismantled other iterations of the archetype: good infanticidal mothers, or those classified as 'mad' in the less divided Australia, instead revealed the underbelly of a degenerate society. Occasionally French journalists began reports on these 'unnatural mothers' by acknowledging the stereotype. According to Le Figaro in 1877, 'almost always, the accused is a factory worker or a domestic servant' who committed infanticide 'to hide her shame'. ${ }^{102}$ Yet the story that followed, of a woman who 'coolly, with a long-time calculated premeditation' poisoned her two-month-old child, 'fulfils completely the conditions in which an infanticide normally presents itself'. ${ }^{103}$

The infanticidal mother's affront to morality often began in her adultery. This was the case for Madame Garsonnet, whose story appeared in Le Figaro in 1876. The wife of a hotel manager, Garsonnet secretly gave birth to two children (the result of affairs with guests), hiding them with wet-nurses in other provinces. 'Surprised by the pains of childbirth' of her third 'error', she threw her latest newborn into a fire. ${ }^{104}$ As the cadaver was burning too slowly, Garsonnet removed it, chopped it into pieces and tossed it into a latrine. In a role reversal, her crime was uncovered by a domestic servant. ${ }^{105}$ The standard narrative was subverted. Garsonnet killed cruelly and calculatedly; she was devoid of maternal instinct; she was the betrayer rather than the betrayed; she had no economic or social imperative to commit infanticide.

99 Jane Laidley and Ada M. Docker, 'Infants' Home, Ashfield: To the Editor', Evening News, 4 July $1889,3$.

100 Ibid.

101 'Gazette des Tribunaux', Figaro, 10 June 1873, 3; 'Chasse aux nouvelles', Croix, 25 February 1897,3 .

102 Fernand de Rodays, ‘Gazette de Tribunaux’, Figaro, 26 May 1877, 3.

103 Ibid.

104 Fernand de Rodays, 'Gazette de Tribunaux', Figaro, 28 February 1876, 3.

105 Ibid. 
Conservative newspapers saw the bad infanticidal mother as a symbol of the Third Republic's immorality and corruption, and used it to exacerbate an already tense political situation. An $1891 \mathrm{La}$ Croix article about a quintuple infanticide connected fears of 'degeneration' with a hatred of Jews, anticipating what Sowerwine labels its 'orgy of antisemitism' during the Dreyfus Affair. ${ }^{106}$ Madame Hayem killed her five children, an indication that 'our era ... is only pushing France backwards'. ${ }^{107}$ Hayem was taken to hospital, where 'her Jewish name awakened the press's sympathies'. ${ }^{108}$ Notable Jewish figures, including press mogul Arthur Meyer, were said to have raised subscriptions, and the government allocated her a pension 50 times the salary of a Parisian domestic servant. ${ }^{109} \mathrm{In}$ a moment epitomising 'the irony of Satan, the king of our century', Hayem was placed in charge of children at a maison hospitaliere. ${ }^{110}$ This rather unbelievable narrative embodied all the fears of La Croix: a Jewish conspiracy to control wealth and information, depopulation, and the spread of 'secularism' to children through education. La Croix fought the tide of anticlericalism through the bad infanticidal mother, using her to illustrate a society so degenerate and morally bankrupt that ideal motherhood was nowhere to be seen.

Although Australian newspapers, including Melbourne's Weekly Times in 1872, ruminated on 'social serpents', 'who intrigue with married men', the good infanticidal mother was normally contrasted with the 'folk devil' of the babyfarmer. ${ }^{111}$ The babyfarmer took money ostensibly to care for the children of poor women, but malnourished them in a cruel form of murder. 'There is a world of distinction,' wrote the Age in 1893, 'between the half-maddened creature who under puerperal excitement destroys her own offspring in a frenzy of fear and shame and the ghouls who make a regular trade of baby murder'. ${ }^{112}$ This distinction lay in the transparency of the babyfarmer's economic motivations. While commentators could dismiss the poverty of good infanticidal mothers, focusing instead upon their 'frenzy of fear and shame', the babyfarmer must be construed as money-hungry.

106 Sowerwine, France since 1870, 70.

107 Jacques de Biez, preface of Les Soeurs et les hôpitaux, in 'L'enfance', Croix, 14 February 1891, 2.

108 Ibid., 1.

109 Ibid., 1-2. For domestic servants' salaries, see Sowerwine, France since 1870, 8.

110 Ibid., 2.

111 'Infanticide', Weekly Times, 2 November 1872, 8; Stanley Cohen, Folk Devils and Moral Panics, 4th ed. (Oxford: Routledge, 2011).

112 Age, 27 December 1893, 4. 
Cases involving the Makins and Frances Knorr made headlines in 1893 and 1894, respectively, serving as powerful examples of the bad infanticidal mother. Infant cadavers were discovered in the backyard of Sarah and John Makin's former Sydney residence, and soon more bodies were found in their other homes. Women came forward, claiming to be the mothers of children whom the Makins, using false names, had adopted for a small fee. Both stood trial for murder and-despite the case relying on circumstantial evidence-were sentenced to death, with Sarah's sentence commuted. ${ }^{113}$ Frances Knorr's previous residences, too, were found to harbour infant cadavers. She was executed, although not without extensive debate. ${ }^{114}$

Both Sarah and Frances had children of their own, yet strayed so far from contemporary understandings of maternity that their womanhood was doubted. A. Jamieson Wrainford saw Knorr as hardly a woman, editorialising: 'it is more by accident of birth than by her own doing that she is what she is'. ${ }^{115}$ Knorr's execution would save her child from 'the debasing influence of its mother, if such a name, suggestive of all that is good, can be applied to a being who ... [doomed children] to a slow and agonising death'. ${ }^{116}$ Knorr had deviated so completely from contemporary definitions - let alone ideals - of 'mother' and 'woman' that she was considered neither. Sarah Makin was referred to as 'the female Makinone can scarcely call her a woman', by the same newspaper, the Launceston Examiner. ${ }^{117}$ These women were no longer mothers but monsters. While the good infanticidal mother had misplaced her maternal instinct, it had disappeared entirely for the babyfarmer. The gravity of her crime was irreconcilable with the notion of the Ideal Mother.

\section{The End of the Archetype}

The infanticidal mother archetype allowed commentators to explore contemporary cultural concerns, traversing urbanity, childcare, femininity and fertility, sometimes within the same article. However, the archetype's primary role-whether she was 'good', 'mad' or 'bad'-was to cement

113 Allen, Sex \& Secrets, 35.

114 Sussex, 'Portrait of a Murderer', 51.

115 A. Jamieson Wrainford, 'Capital Punishment', Launceston Examiner, 3 March 1894, 10.

116 Ibid.

117 Launceston Examiner, 18 November 1892, 2. 
the idealisation of motherhood. In Australia, commentators denied the infanticidal mother rationality and agency, resulting in the belief in puerperal mania and the scapegoating of babyfarmers. In France, journalists used the archetype to examine not only infanticide but the viability of the Third Republic itself. The gulf between conservative and progressive papers and citizens was wider, meaning the archetype was mobilised for a greater number of political ends than in Australia. But both nations embraced maternal instinct-often misplaced and sometimes permanently lost. Matthews argues that 'morally and economically, single motherhood was a contradiction in terms', barring women with illegitimate children from experiencing 'the prize' of motherhood. ${ }^{118}$ However, infanticidal women were not only allowed to reattempt motherhood, they were expected to do so-both for their own wellbeing and the health of their nation.

Prior to the First World War, a series of legal and social changes in both countries led to a severe drop in recorded infanticides. The new curettage technique made abortion significantly safer, albeit more expensive and still illegal. ${ }^{19}$ France changed the penal code in 1901 to reflect the reality of how infanticide was prosecuted; the minimum term of punishment became two years imprisonment. ${ }^{120}$ Several French laws increased paternal responsibility, culminating in the legalisation of a limited number of paternity suits in $1912 .{ }^{121}$ From the same year, white women in Australiaregardless of marital status - could receive a $£ 5$ bonus to finance the care of their newborns. ${ }^{122}$ As war loomed closer, population anxieties were exacerbated, and infanticide featured in fewer headlines.

Infanticidal mothers committed three major transgressions: they had extra-marital sex, gave birth to illegitimate children and killed their offspring. But commentator's willingness to extend sympathy to these women is not an example of a more permissive past on which we should model our own gender relations. Rather, this seeming compassion obscured an unwillingness to see women as rational and to attend to their interests. The cultural prominence of the infanticidal mother archetype ended long ago, but this is only one of many ways discourses of femininity have been-and continue to be-used to neutralise threats to gender norms

118 Matthews, Good and Mad Women, 180.

119 Allen, Sex \& Secrets, 70; Huber, 'Sex and its Consequences', 134.

120 Lalou, 'L'infanticide devant les tribunaux français', 191.

121 Fuchs, Contested Paternity, 105.

122 Brian Reid, 'Masculinity of Birth Registrations in Australia, 1880-1915: Another Aspect of the Population Debate', Health and History, 2, no. 1 (2000): 151. 
and, by extension, the state. Examining the infanticidal mother allows us to glimpse this work in action cross-culturally; to see how 'La Petite Mary' existed alongside Frances Knorr, how feminist utopias shared common ground with conservative horror stories, and how women who calmly took the dilemma of pregnancy into their own hands were deemed mad. 
This text is taken from Lilith: A Feminist History Journal: Number 27, published 2021 by ANU Press, The Australian National University,

Canberra, Australia.

doi.org/10.22459/LFHJ.27.09 